\title{
The Next Big Idea
}

\author{
Marian Rewers, MD, PhD
}

\begin{abstract}
George S. Eisenbarth will remain in our memories as a brilliant scientist and great collaborator. His quest to discover the cause and prevention of type 1 (autoimmune) diabetes started from building predictive models based on immunogenetic markers. Despite his tremendous contributions to our understanding of the natural history of pre-type 1 diabetes and potential mechanisms, George left us with several big questions to answer before his quest is completed.
\end{abstract}

\section{Overture}

S O, WHAT IS THE NEXT BIG IDEA we should be working on?" was usually the second sentence George would say during our annual faculty evaluation meetings, right after a brief compliment on a great job one had done the previous year. This was his way to move quickly to where he felt comfortable and away from formal evaluation that he disregarded as a potentially antagonizing bureaucratic ritual. He would ask this question on other occasions, especially in late afternoons, seemingly looking for a reward after a hard day's work.

The first time I heard him say that was during our first meeting at the International Diabetes Federation Congress in Sydney, Australia, in 1988. At a press conference, he was interviewed about the early version of his famed model predicting the risk of type 1 diabetes (T1D) using age, insulin autoantibody levels, and insulin response to intravenous glucose. ${ }^{1}$ Based on his previous work on immunogenetics of $\mathrm{T} 1 \mathrm{D},{ }^{2}$ George painted a strong picture of T1D being a genetically determined disease with a predictable preclinical course.

A few minutes later, I answered questions on behalf of the Diabetes Epidemiology Research International Group, reporting, for the first time, that the incidence of T1D had been rising by $3-5 \%$ a year, since the mid-1960s, in most of the 21 ethnic groups from 10 countries that we studied. ${ }^{3}$ This temporal trend suggested that T1D was an environmentally determined disease rising across genetically diverse populations. ${ }^{3}$ This apparent paradox led to a fascinating conversation (at least from my postdoc point of view), and we agreed that solving the gene-environment puzzle of T1D was a big idea worth pursuing.

We have not talked again until an unlikely Denver, CO, meeting, in September 1991, arranged by Dick Hamman, Chair of Preventive Medicine and Biometrics and my mentor. Dick was part of the search committee for a new executive director of the Barbara Davis Center for Childhood Diabetes
(BDC). Going out of town, he offered me (a fledgling assistant professor) the opportunity to meet with one of the candidates - the famous George Eisenbarth. I doubt that anybody ever read my evaluation of George following that meeting, but this gave me the bragging rights for "hiring" George, rights that truly belong to Dick Krugman (Dean of University of Colorado School of Medicine) and Doug Jones (Chair of Pediatrics).

After a few awkward minutes, George asked me, "So, what is the next big idea we should be working on?" There was a lot to talk about. Four months earlier, Dick Hamman asked me to help renew his National Institutes of Health (NIH) RO1 grant "Colorado IDDM Registry." In the application submitted in June 1991, I wrote a specific aim proposing a cohort study of genetically high-risk children followed to development of islet cell autoantibodies (ICA) and T1D called the Diabetes AutoImmunity Study in the Young (DAISY). We proposed to search prospectively for potential environmental triggers of T1D in infant first-degree relatives of T1D patients and in genetically high-risk children with no family history of T1D. This was a novel idea that occurred to me during a long flight home from a "brain storming" meeting organized by Hans Akerblom in Helsinki, Finland, in December 1990. At that time, the idea seemed crazy or at least impractical given the low risk of T1D in the general population and low predictive value of human leukocyte antigen (HLA) genotypes. It was incredibly reassuring to hear from George that this could be the next "big idea." He recommended contacting Henry Erlich, Director of Human Genetics at Roche Molecular, Inc. (Alameda, CA), to find out if a large-scale newborn screening for high-risk HLA genotypes would be feasible.

The NIH RO1 payline stood then, as today, at 7\%. The study section liked the idea but was concerned whether we could define the prediabetes phenotype using ICA alone. George's laboratory, one of the two or three leaders in the field at that time, would solve these concerns immediately. We were elated when he accepted the University of Colorado's

Barbara Davis Center for Diabetes, University of Colorado School of Medicine, Aurora, Colorado. 
offer to become BDC Executive Director, in April 1992. In September, he moved his laboratory to Denver and wrote in his support letter:

I will be able to strengthen the ability of the Center to participate in and contribute to the studies Dr. Rewers has outlined. In particular, my laboratory shares an intense interest in the immunologic events leading to the activation of autoimmunity and have developed a series of new assays including the discovery of several new autoantigens which could be applied to samples from this surveillance effort. [...] these studies I believe are essential to the unraveling of the natural history of type I diabetes.

A few months later, DAISY (my first RO1) was funded. ${ }^{4,5}$ Although George and I remained in different departments until late 2000, our collaboration grew stronger every year, leading eventually to 83 joint peer-reviewed articles, including 70 based on the DAISY cohort.

\section{Act 1: DAISY \\ Immunogenetics}

Over the next 20 years, DAISY made major contributions to our understanding of the etiology of T1D. DAISY was first to study the natural history of islet autoantibodies and the risk factors for progression to diabetes in children without a family history of T1D where more than $90 \%$ of T1D cases occur. ${ }^{6} \mathrm{We}$ discovered that among children with identical $H L A-D R, D Q$ genotypes, the incidence of islet autoimmunity was dramatically higher in children with, compared with those without, a first-degree relative with diabetes, ${ }^{7}$ pointing to the importance of environmental factors and/or non-HLA Class II genes. DAISY reported the first-ever population-based estimates of the incidence of islet autoimmunity in general population children. ${ }^{8}$ Although islet autoantibodies were found in $3.7 \%$ of cord blood samples, they appeared to be maternal of origin and were not predictive of subsequent development of islet autoimmunity. ${ }^{9}$ DAISY demonstrated that over $70 \%$ of children expressing multiple islet autoantibodies progress to diabetes in 10 years compared with $15 \%$ of those with one autoantibody. Once islet autoimmunity spreads to more than one autoantigen, the progression to T1D is only a matter of time; the rate of progression is linear and hardly influenced by the $H L A-D R, D Q$ genotype or family history of T1D. The age of appearance of first autoantibody and the levels of insulin autoantibodies (but not glutamic acid decarboxylase 65 or islet antigen 2) are major determinants of the age of onset of diabetes. $^{10}$

DAISY newborn screening of the multiethnic Denver population and comparisons with the local T1D patient population led to novel observations: $D R 4, D Q B 1^{*} 0302$ haplotypes are more frequent in Hispanics and confer lower T1D risk in this ethnic group than in non-Hispanic whites, whereas $D R 3, D Q B 1 * 0201$ haplotypes are much less frequent but carry similar risk to that in non-Hispanic whites. ${ }^{11} D R B 1^{*} 04$ subtypes confer additional risk ${ }^{12}$ in both groups. In collaboration with Janelle Noble and Henry Erlich, we found HLA$D P B 1^{*} 0402$ to be protective, even in subjects with the highrisk $D R 3 / 4, D Q B 1^{*} 0302$ genotype. ${ }^{13}$ The $H L A-A^{*} 0101 / 0201$ genotype increases the risk, ${ }^{14}$ whereas the HLA-B39 allele determines the risk on $H L A-D R 8$ haplotypes. These discov- eries have been translated into improved newborn screening protocols. ${ }^{15,16}$

Many of the DAISY contributions to the genetics of T1D have been led by George and his outstanding Fellows. Akane Ide, Terry Aly, Erin Baschal, and Mohamed Jahromi have explored in the DAISY population additional genetic determinants within the major histocompatibility complex (MHC) region. They found the extreme difference in the risk of islet autoantibodies between $D R 3 / 4, D Q B 1{ }^{*} 0302$ siblings sharing both HLA haplotypes by descent with the T1D proband, versus those sharing one or no haplotypes ( $85 \%$ vs. $15 \%$ by 12 years of age). ${ }^{17}$ The insulin (INS), tyrosine-protein phosphatase non-receptor type 22 (PTPN22), MHC class I chain-related A $(M I C-A),{ }^{18} H L A-D R B 1^{*} 04$, or HLA-DP genotypes did not explain this remarkable risk difference. The conserved haplotype DQ2,DR3,MIC-A5.1,HLA-B8,HLA-Cw7,HLA-A1,D6S2223$177^{19}$ was the predominant DR3 haplotype in islet autoimmunity, but it was not differentially transmitted from parents to affected children. ${ }^{19-22}$ An additional major genetic locus determining T1D was identified in linkage with but distinct from high-risk $D R, D Q$ alleles. ${ }^{17,23-25}$

Nearly 50 non-HLA gene variants have been associated with T1D in genome-wide association studies, however, jointly explaining a small part of the familial aggregation not explained by $\mathrm{MHC}^{26}$ Andrea Steck, George, and I began a systematic evaluation of these markers as predictors of islet autoimmunity and T1D in the DAISY cohort. The PTPN22 C1858T polymorphisms further accelerated development of islet autoimmunity and T1D, independently of the HLA$D R, D Q,{ }^{27,28}$ whereas the CCR5 $\Delta 32$ allele was protective. The significant, but relatively minor, role of the cytotoxic T-lymphocyte A (CTLA)-4-318 and interferon induced with helicase $C$ domain 1 polymorphism was confirmed, and we have reported novel associations between polymorphisms in interleukin-4R, interleukin-4, and interleukin-13 and islet autoimmunity. ${ }^{29}$ We discovered that the high-risk phenotype of persistently high level of insulin autoantibodies is strongly $(P<0.0001)$ associated with the INS-23HphI A/A genotype conferring higher risk of T1D. ${ }^{10}$

\section{Dietary factors}

In articles led by Jill Norris, DAISY refuted earlier, highly publicized hypotheses linking T1D to shorter breast-feeding and cow's milk formulas. ${ }^{30,31}$ On the other hand, we discovered that higher $\omega-3$ fatty acid intake and higher $\omega-3$ fatty acid red blood cell membrane levels were associated with lower risk of islet autoimmunity in children at increased genetic risk for T1D. ${ }^{32}$ However, neither $\omega-3$ fatty acid intake nor levels were associated with progression to T1D in children with islet autoimmunity, suggesting that the protective role of fatty acids may be early in the process. ${ }^{33}$ It is interesting that plasma 25-hydroxy-vitamin D levels were not associated with the risk of islet autoimmunity or progression to T1D, nor were there significant interactions between vitamin $\mathrm{D}$ levels and polymorphisms in the vitamin D receptor, INS, PTPN22, or CTLA-4 gene on islet autoimmunity or T1D risk. ${ }^{34}$ One of the most intriguing findings was increased risk of islet autoimmunity with exposure to cereals (both gluten-free and glutencontaining) before 4 or after 6 months, compared with those exposed in the 4-6-month "window." ${ }^{31}$ The specific causative component of cereals is still unknown. Exposure to 
gluten-containing cereals outside this "window" increased the development of celiac disease ${ }^{35}$ and allergy. ${ }^{36}$

\section{Infectious agents}

With Lars Stene and Janet Snell-Bergeon, we found that children whose mothers reported at least one infection during pregnancy had a significantly lower risk of islet autoimmunity compared with other children. ${ }^{37}$ Older maternal age and complicated delivery predicted islet autoimmunity, ${ }^{38}$ but cesarean section or neonatal infections did not. More frequent respiratory infections during infancy (but not early daycare attendance or household crowding) reduced the risk of islet autoimmunity. ${ }^{39}$ Thus, DAISY results concerning pre- and postnatal infections appear to be consistent with the "hygiene hypothesis" linking decreasing number of early childhood infections with autoimmunity. ${ }^{40,41}$ Previously, we found with Patricia Graves that enteroviral infections detected by polymerase chain reaction testing of serum, saliva, and rectal swab samples did not predict islet autoimmunity in high-risk children. ${ }^{42}$ A systematic search for nucleic acids of multiple pathogens in plasma, saliva, throat, and rectal swab samples collected before and after development of islet autoimmunity in 58 DAISY cases and in 107 matched controls detected multiple infections but no associations with T1D (G. Palacios and I. Lipkin, unpublished data, 2010). We were also unable to confirm an association between rotaviral infections and T1D. However, our follow-up study in collaboration with Lars Stene and Heikki Hyöty demonstrated that enteroviral infections may increase the risk of progression from islet autoimmunity to T1D. ${ }^{43}$ Preliminary virus sequencing showed no evidence for persistence of a specific virus in children progressing to T1D; rather, recurrent infections with unrelated strains may be the final $\beta$-cell insult leading to hyperglycemia, in some cases.

\section{Translation to clinical practice}

DAISY findings had an immediate and reassuring impact on public perception of potential causes of T1D. It provided evidence that routine immunizations and their timing ${ }^{42}$ as well as breast-feeding duration and age at cow's milk exposure did not lead to development of islet autoantibodies, ${ }^{30,31}$ confirmed later by prospective studies in Germany ${ }^{44}$ and Finland. ${ }^{45}$ Normal but increasing hemoglobin A1c levels for up to 2 years prior to diagnosis foreshadows progression to $\mathrm{T}^{4} \mathrm{D}^{46}$ - an important observation for potential change in diabetes diagnostic criteria. Children followed by DAISY to diabetes have avoided diabetic ketoacidosis and hospitalization at diagnosis and had higher C-peptide levels and lower blood glucose levels, hemoglobin A1c levels, and insulin doses during the initial year post-diagnosis than community controls. ${ }^{47}$ This indicates preservation of endogenous insulin that may lower the risk of microvascular complications and severe hypoglycemia. ${ }^{48}$

George's laboratory, in collaboration with DAISY has participated in development and validation of multiple serologic assays for detection of islet autoimmunity, ${ }^{49-59}$ celiac disease, ${ }^{60-65}$ and other autoimmune disorders. ${ }^{54,66-72}$ DAISY has contributed significantly to the "discovery" of celiac disease as a common disease in the U.S. general population ${ }^{65,73-76}$ and special groups. ${ }^{77-79}$ We have extensively studied the relationship between islet autoimmunity and celiac autoim- munity ${ }^{77-81}$ and begun to disentangle the common mechanisms of islet autoimmunity and celiac, thyroid, adrenal, parietal cell, and rheumatoid autoimmunities. ${ }^{68,82,83}$

\section{Intermezzo: People, Space, and Money}

Looking back, the fascinating research discussions and findings that I have shared with George can be nicely arranged into a string of ideas, grants, and articles. Intermixed with those, there was the other business-running the BDC. I started seeing children with diabetes at the BDC shortly after George's arrival; over time, he invited me to direct the Center's Translational Research Unit and, eventually, the Clinical Division-approximately 40 employees. I joined him and John Hutton (Research Division Director) in December of 2000 and immediately faced a triple challenge: (1) to build up the clinical team in order to meet an exponential growth of our patient population, (2) to expand clinical/translational research, and (3) to find enough space to accommodate both. During the following 8 years later, we quadrupled our staff, funding, and space. The Center is now seeing 6,000 children and adults with T1D_among the largest populations anywhere in the world. The talent (Georgeanna Klingensmith, Satish Garg, and Rob Slover, to mention just a few on the clinical side), hard work, and good luck were on our side.

George was a visionary, brilliant scientist, wonderful boss and mentor. The culture he created at the BDC was positive, predictable without a lot of overt conflict. When he took over, the BDC was already famous and successful because of the accomplishments of Peter Chase, Kevin Lafferty, and others, but small by the current standards. His high personal scientific standing and the generous support of the Children's Diabetes Foundation have been the major drivers of the Center's exponential growth. George has helped to recruit and retain the best talent by focusing on the big picture, taking risks and responding to opportunities to benefit the BDC. One of them was his bold decision to move to Fitzsimons (now called Anschutz Medical Center) as one of the first units of the Medical School. This paid off well, with a beautiful four-story 110,000 square feet building. We also had a good luck to operate in uniquely favorable research funding environment created by the NIH Special Statutory Funds for Type 1 Diabetes Research (nationally over $\$ 2$ billion since, 1998) and the Juvenile Diabetes Research Foundation. The BDC has benefited enormously from their support. More about this fascinating part of our lives can be found in a book recently written by $\mathrm{H}$. Peter Chase and Sue Palandri. ${ }^{84}$

\section{Act 2: TEDDY}

The success of DAISY and similar studies has not been lost on the research community. Through a series of international workshops supported by the American Diabetes Association, the Juvenile Diabetes Research Foundation, and the NIH, we were able to convince the NIH to combine our efforts with those of our colleagues in Finland, Germany, Sweden, Seattle, WA, and Augusta, GA/Gainesville, FL.

The Environmental Determinants of Diabetes in the Young (TEDDY) study was initiated in 2002 to identify infectious agents, dietary factors, or other environmental exposures that may trigger or protect against the development of islet autoimmunity and T1D. ${ }^{15,85}$ DAISY had piloted the key components of the protocol for TEDDY. By July 2010, in total, 424,788 
newborns have been screened by $H L A-D R, D Q$ genotyping to identify children at increased risk for T1D, and 8,677 have been enrolled to be followed four times a year until 4 years of age and twice a year thereafter until 15 years of age. ${ }^{86} \mathrm{~A}$ successful study outcome should allow better understanding of the etiology and pathogenesis of islet autoimmunity and T1D and the development of new strategies to prevent, delay, or reverse the disease.

George, Liping $\mathrm{Yu}$, and I jump-started the international effort to "harmonize" islet autoimmunity assays ${ }^{87}$ for TEDDY and other consortia. Although his eyes were already set at new ideas and experiments, ${ }^{88,89}$ George remained supportive and active on the TEDDY Immune Markers Committee.

\section{Finale: Primary Prevention of T1D in the General Population}

One day, and it is hoped soon, TEDDY will tell us how to modify our children's environment to stop islet autoimmunity before it even develops. In the meantime, we are getting very close to the point where millions of children could be screened for islet autoantibodies two or three times during the initial 12 years of life and those found positive could be enrolled in prevention trials. George's work has paved the path to robust, inexpensive autoantibody assays and predictive models. This was one of the big ideas that I promised him to continue work on. Unfortunately, he was not given sufficient time to develop durable intervention that would prevent progression from islet autoimmunity to diabetes, but his belief that insulin is the key autoantigen is being addressed by quite a few groups, and new "big ideas" will undoubtedly follow.

\section{Author Disclosure Statement}

No competing financial interests exist.

\section{References}

1. Jackson RA, Soeldner JS, Eisenbarth GS: Predicting insulindependent diabetes. Lancet 1988;2:627-628.

2. Eisenbarth GS: Lilly Lecture 1986. Genes, generator of diversity, glycoconjugates, and autoimmune beta-cell insufficiency in type I diabetes. Diabetes 1987;36:355-364.

3. Diabetes Epidemiology Research International Group: Secular trends in incidence of childhood IDDM in 10 countries. Diabetes Epidemiology Research International Group. Diabetes 1990;39:858-864.

4. Rewers M, Bugawan TL, Norris JM, Blair A, Beaty B, Hoffman M, McDuffie RS Jr, Hamman RF, Klingensmith G, Eisenbarth GS, Erlich HA: Newborn screening for HLA markers associated with IDDM: Diabetes Autoimmunity Study in the Young (DAISY). Diabetologia 1996;39:807-812.

5. Norris JM, Beaty B, Klingensmith G, Yu L, Hoffman M, Chase HP, Erlich HA, Hamman RF, Eisenbarth GS, Rewers M: Lack of association between early exposure to cow's milk protein and beta-cell autoimmunity. Diabetes Autoimmunity Study in the Young (DAISY). JAMA 1996;276: 609-614.

6. Steck AK, Barriga KJ, Emery LM, Fiallo-Scharer RV, Gottlieb PA, Rewers MJ: Secondary attack rate of type 1 diabetes in Colorado families. Diabetes Care 2005;28:296-300.

7. Rewers M, Eisenbarth GE, Norris JM, Erlich H, Beaty B, Klingensmith G, Elliott RB: Population and familial risk of beta-cell autoimmunity in the first two years of life: Diabetes
Autoimmunity Study in the Young [abstract]. Diabetologia 1996;39(Suppl 1):15.

8. Barker JM, Barriga KJ, Yu L, Miao D, Erlich HA, Norris JM, Eisenbarth GS, Rewers M: Prediction of autoantibody positivity and progression to type 1 diabetes: Diabetes Autoimmunity Study in the Young (DAISY). J Clin Endocrinol Metab 2004;89:3896-3902.

9. Stanley HM, Norris JM, Barriga K, Hoffman M, Yu L, Miao D, Erlich HA, Eisenbarth GS, Rewers M: Is presence of islet autoantibodies at birth associated with development of persistent islet autoimmunity? The Diabetes Autoimmunity Study in the Young (DAISY). Diabetes Care 2004;27:497-502.

10. Steck AK, Johnson K, Barriga KJ, Miao D, Yu L, Hutton JC, Eisenbarth GS, Rewers MJ: Age of islet autoantibody appearance and mean levels of insulin, but not GAD or IA-2 autoantibodies, predict age of diagnosis of type 1 diabetes: Diabetes Autoimmunity Study in the Young. Diabetes Care 2011;34:1397-1399.

11. Emery LM, Babu S, Bugawan TL, Norris JM, Erlich HA, Eisenbarth GS, Rewers M: Newborn HLA-DR,DQ genotype screening: age- and ethnicity-specific type 1 diabetes risk estimates. Pediatr Diabetes 2005;6:136-144.

12. Rewers A, Babu S, Wang TB, Bugawan TL, Barriga K, Eisenbarth GS, Erlich HA: Ethnic differences in the associations between the HLA-DRB1*04 subtypes and type 1 diabetes. Ann N Y Acad Sci 2003;1005:301-309.

13. Baschal EE, Aly TA, Babu SR, Fernando MS, Yu L, Miao D, Barriga KJ, Norris JM, Noble JA, Erlich HA, Rewers M, Eisenbarth GS: HLA-DPB1*0402 protects against type 1A diabetes autoimmunity in the highest risk DR3-DQB1*0201/ DR4-DQB1*0302 DAISY population. Diabetes 2007;56:24052409.

14. Robles DT, Eisenbarth GS, Wang T, Erlich HA, Bugawan TL, Babu SR, Barriga K, Norris JM, Hoffman M, Klingensmith G, Yu L, Rewers M: Millennium award recipient contribution. Identification of children with early onset and high incidence of anti-islet autoantibodies. Clin.Immunol 2002;102: 217-224.

15. The Environmental Determinants of Diabetes in the Young (TEDDY) study: study design. Pediatr Diabetes 2007;8:286298.

16. Barker JM, Triolo TM, Aly TA, Baschal EE, Babu SR, Kretowski A, Rewers MJ, Eisenbarth GS: Two single nucleotide polymorphisms identify the highest-risk diabetes HLA genotype: potential for rapid screening. Diabetes 2008;57:3152-3155.

17. Aly TA, Ide A, Jahromi MM, Barker JM, Fernando MS, Babu SR, Yu L, Miao D, Erlich HA, Fain PR, Barriga KJ, Norris JM, Rewers MJ, Eisenbarth GS: Extreme genetic risk for type 1A diabetes. Proc Natl Acad Sci U S A 2006;103:14074-14079.

18. Ide A, Babu SR, Robles DT, Wang T, Erlich HA, Bugawan TL, Rewers M, Fain PR, Eisenbarth GS: Homozygosity for premature stop codon of the MHC class I chain-related gene A (MIC-A) is associated with early activation of islet autoimmunity of DR3/4-DQ2/8 high risk DAISY relatives. J Clin Immunol 2005;25:303-308.

19. Ide A, Babu SR, Robles DT, Wang T, Erlich HA, Bugawan TL, Rewers M, Fain PR, Eisenbarth GS: "Extended" A1, B8, DR3 haplotype shows remarkable linkage disequilibrium but is similar to nonextended haplotypes in terms of diabetes risk. Diabetes 2005;54:1879-1883.

20. Aly TA, Eller E, Ide A, Gowan K, Babu SR, Erlich HA, Rewers MJ, Eisenbarth GS, Fain PR: Multi-SNP analysis of MHC region: remarkable conservation of HLA-A1-B8-DR3 haplotype. Diabetes 2006;55:1265-1269. 
21. Baschal EE, Aly TA, Jasinski JM, Steck AK, Noble JA, Erlich HA, Eisenbarth GS: Defining multiple common "completely" conserved major histocompatibility complex SNP haplotypes. Clin Immunol 2009;132:203-214.

22. Baschal EE, Aly TA, Jasinski JM, Steck AK, Johnson KN, Noble JA, Erlich HA, Eisenbarth GS: The frequent and conserved DR3-B8-A1 extended haplotype confers less diabetes risk than other DR3 haplotypes. Diabetes Obes.Metab 2009;11(Suppl 1):25-30.

23. Aly TA, Ide A, Humphrey K, Barker JM, Steck A, Erlich HA, Yu L, Miao D, Redondo MJ, McFann K, Roberts CM, Babu SR, Norris JM, Eisenbarth GS, Rewers MJ: Genetic prediction of autoimmunity: initial oligogenic prediction of anti-islet autoimmunity amongst DR3/DR4-DQ8 relatives of patients with type 1A diabetes. J Autoimmun 2005;25(Suppl):40-45.

24. Aly TA, Baschal EE, Jahromi MM, Fernando MS, Babu SR, Fingerlin TE, Kretowski A, Erlich HA, Fain PR, Rewers MJ, Eisenbarth GS: Analysis of single nucleotide polymorphisms identifies major type $1 \mathrm{~A}$ diabetes locus telomeric of the major histocompatibility complex. Diabetes 2008;57:770-776.

25. Baschal EE, Eisenbarth GS: Extreme genetic risk for type 1A diabetes in the post-genome era. J Autoimmun 2008;31:1-6.

26. Clayton DG: Prediction and interaction in complex disease genetics: experience in type 1 diabetes. PLoS Genet 2009;5:e1000540.

27. Steck AK, Liu SY, McFann K, Barriga KJ, Babu SR, Eisenbarth GS, Rewers MJ, She JX: Association of the PTPN22/LYP gene with type 1 diabetes. Pediatr Diabetes 2006;7:274-278.

28. Steck AK, Zhang W, Bugawan TL, Barriga KJ, Blair A, Erlich HA, Eisenbarth GS, Norris JM, Rewers MJ: Do non-HLA genes influence development of persistent islet autoimmunity and type 1 diabetes in children with high-risk HLADR,DQ genotypes? Diabetes 2009;58:1028-1033.

29. Steck AK, Bugawan TL, Valdes AM, Emery LM, Blair A, Norris JM, Redondo MJ, Babu SR, Erlich HA, Eisenbarth GS, Rewers MJ: Association of non-HLA genes with type 1 diabetes autoimmunity. Diabetes 2005;54:2482-2486.

30. Norris JM, Eisenbarth GS, Beaty B, Giclas P, Yu L, Klingensmith $G$, Rewers M: Dietary antibodies, infant diet and beta-cell autoimmunity: Diabetes Autoimmunity Study in the Young (DAISY) [abstract]. Autoimmunity 1995;21:22-A082.

31. Norris JM, Barriga K, Klingensmith G, Hoffman M, Eisenbarth GS, Erlich HA, Rewers M: Timing of initial cereal exposure in infancy and risk of islet autoimmunity. JAMA 2003;290:1713-1720.

32. Norris JM, Yin X, Lamb MM, Barriga K, Seifert J, Hoffman M, Orton HD, Baron AE, Clare-Salzler M, Chase HP, Szabo NJ, Erlich H, Eisenbarth GS, Rewers MJ: Omega-3 polyunsaturated fatty acid intake and islet autoimmunity in children at increased risk for type 1 diabetes. JAMA 2007; 298:1420-1428.

33. Norris JM, Yin X, Miller MR, Clare-Salzer M, Rewers M: Erythrocyte membrane omega-3 fatty acid levels are not associated with the conversion to type 1 diabetes in children with islet autoimmunity. The Diabetes Autoimmunity Study in the Young (DAISY) [abstract]. Diabetes 2010;59(Suppl 1):A72.

34. Simpson M, Brady H, Eisenbarth GS, Rewers M, Erlich HA, Norris JM: No association between vitamin D levels and the risk for islet autoimmunity and type 1 diabetes: DAISY. Diabetologia 2009;52(Suppl 1):S118-S119.

35. Norris JM, Barriga K, Hoffenberg EJ, Taki I, Miao D, Haas JE, Emery LM, Sokol RJ, Erlich HA, Eisenbarth GS, Rewers
M: Risk of celiac disease autoimmunity and timing of gluten introduction in the diet of infants at increased risk of disease. JAMA 2005;293:2343-2351.

36. Poole JA, Barriga K, Leung DY, Hoffman M, Eisenbarth GS, Rewers M, Norris JM: Timing of initial exposure to cereal grains and the risk of wheat allergy. Pediatrics 2006;117: 2175-2182.

37. Stene LC, Barriga K, Norris JM, Hoffman M, Klingensmith G, Erlich HA, Eisenbarth GS, Rewers M: Symptoms of common maternal infections in pregnancy and risk of islet autoimmunity in early childhood. Diabetes Care 2003;26: 3136-3141.

38. Stene LC, Barriga $K$, Norris JM, Hoffman M, Erlich HA, Eisenbarth GS, McDuffie RS Jr, Rewers M: Perinatal factors and development of islet autoimmunity in early childhood: the Diabetes Autoimmunity Study in the Young. Am J Epidemiol 2004;160:3-10.

39. Snell-Bergeon JK, Smith J, Dong F, Baron AE, Barriga $K$, Norris JM, Rewers M: Early childhood infections and the risk of islet autoimmunity: the Diabetes Autoimmunity Study in the Young (DAISY). Diabetes Care 2012;35:2553-2558.

40. Strachan DP: Hay fever, hygiene, and household size. BMJ 1989;299:1259-1260.

41. Chatenoud L, You S, Okada H, Kuhn C, Michaud B, Bach JF: 99th Dahlem conference on infection, inflammation and chronic inflammatory disorders: immune therapies of type 1 diabetes: new opportunities based on the hygiene hypothesis. Clin Exp Immunol 2010;160:106-112.

42. Graves PM, Barriga KJ, Norris JM, Hoffman MR, Yu L, Eisenbarth GS, Rewers M: Lack of association between early childhood immunizations and beta-cell autoimmunity. Diabetes Care 1999;22:1694-1697.

43. Stene LC, Oikarinen S, Hyöty H, Barriga KJ, Norris JM, Klingensmith GJ, Hutton JC, Erlich HA, Eisenbarth GS, Rewers M: Enterovirus infection and progression from islet autoimmunity to type 1 diabetes: the Diabetes and Autoimmunity Study in the Young (DAISY). Diabetes 2010;59: 3174-3180.

44. Ziegler AG, Schmid S, Huber D, Hummel M, Bonifacio E: Early infant feeding and risk of developing type 1 diabetesassociated autoantibodies. JAMA 2003;290:1721-1728.

45. Virtanen SM, Kenward MG, Erkkola M, Kautiainen S, Kronberg-Kippila C, Hakulinen T, Ahonen S, Uusitalo L, Niinisto S, Veijola R, Simell O, Ilonen J, Knip M: Age at introduction of new foods and advanced beta cell autoimmunity in young children with HLA-conferred susceptibility to type 1 diabetes. Diabetologia 2006;49:1512-1521.

46. Stene LC, Barriga K, Hoffman M, Kean J, Klingensmith G, Norris JM, Erlich HA, Eisenbarth GS, Rewers M: Normal but increasing hemoglobin A1c levels predict progression from islet autoimmunity to overt type 1 diabetes: Diabetes Autoimmunity Study in the Young (DAISY). Pediatr Diabetes 2006;7:247-253.

47. Barker JM, Goehrig SH, Barriga K, Hoffman M, Slover R, Eisenbarth GS, Norris JM, Klingensmith GJ, Rewers M: Clinical characteristics of children diagnosed with type 1 diabetes through intensive screening and follow-up. Diabetes Care 2004;27:1399-1404.

48. Steffes MW, Sibley S, Jackson M, Thomas W: Beta-cell function and the development of diabetes-related complications in the diabetes control and complications trial. Diabetes Care 2003;26:832-836.

49. Wenzlau JM, Juhl K, Yu L, Moua O, Sarkar SA, Gottlieb P, Rewers M, Eisenbarth GS, Jensen J, Davidson HW, Hutton 
JC: The cation efflux transporter ZnT8 (Slc30A8) is a major autoantigen in human type 1 diabetes. Proc Natl Acad Sci U S A 2007;104:17040-17045.

50. Yu L, Miao D, Scrimgeour L, Johnson K, Rewers M, Eisenbarth GS: Distinguishing persistent insulin autoantibodies with differential risk: nonradioactive bivalent proinsulin/insulin autoantibody assay. Diabetes 2012;61:179-186

51. Babaya N, Yu L, Miao D, Wang J, Rewers M, Nakayama M, Liu E, Barker JM, Eisenbarth GS: Comparison of insulin autoantibody: polyethylene glycol and micro-IAA 1-day and 7-day assays. Diabetes Metab Res Rev 2009;25:665-670.

52. Babaya N, Liu E, Miao D, Li M, Yu L, Eisenbarth GS: Murine high specificity/sensitivity competitive europium insulin autoantibody assay. Diabetes Technol Ther 2009;11:227-233.

53. Gianani R, Rabin DU, Verge CF, Yu L, Babu SR, Pietropaolo M, Eisenbarth GS: ICA512 autoantibody radioassay. Diabetes 1995;44:1340-1344.

54. Kawasaki E, Eisenbarth GS: High-throughput radioassays for autoantibodies to recombinant autoantigens. Front Biosci 2000;5:E181-E190.

55. Liu Y, Wenzlau JM, Yu L, Patel C, Eisenbarth GS, Hutton JC, Davidson HW: Conserved epitopes in the protein tyrosine phosphatase family of diabetes autoantigens. Ann N Y Acad Sci 2008;1150:245-247.

56. Maniatis AK, Yu L, Miao D, Nelson K, Eisenbarth GS: Rapid assays for detection of anti-islet autoantibodies: implications for organ donor screening. J Autoimmun 2001;16:71-76.

57. Miao D, Yu L, Tiberti C, Cuthbertson DD, Rewers M, di Mario U, Eisenbarth GS, Dotta F: ICA512(IA-2) epitope specific assays distinguish transient from diabetes associated autoantibodies. J Autoimmun 2002;18:191-196.

58. Tiberti C, Yu L, Lucantoni F, Panimolle F, Spagnuolo I, Lenzi A, Eisenbarth GS, Dotta F: Detection of four diabetes specific autoantibodies in a single radioimmunoassay: an innovative high-throughput approach for autoimmune diabetes screening. Clin Exp Immunol 2011;166:317-324.

59. Yu L, Liu Y, Miao D, Wenzlau J, Davidson H, Hutton J, Eisenbarth GS: Triple chimeric islet autoantigen IA2ZnT8WR to facilitate islet autoantibody determination. J Immunol Methods 2010;353:20-23.

60. Liu E, Bao F, Barriga K, Miao D, Yu L, Erlich HA, Haas JE, Eisenbarth GS, Rewers MJ, Hoffenberg EJ: Fluctuating transglutaminase autoantibodies are related to histologic features of celiac disease. Clin Gastroenterol Hepatol 2003;1: 356-362.

61. Liu E, Li M, Emery L, Taki I, Barriga K, Tiberti C, Eisenbarth GS, Rewers MJ, Hoffenberg EJ: Natural history of antibodies to deamidated gliadin peptides and transglutaminase in early childhood celiac disease. J Pediatr Gastroenterol Nutr 2007;45:293-300.

62. Bao F, Yu L, Babu S, Wang T, Hoffenberg EJ, Rewers M, Eisenbarth GS: One third of HLA DQ2 homozygous patients with type 1 diabetes express celiac disease-associated transglutaminase autoantibodies. J Autoimmun 1999;13:143-148.

63. Li M, Yu L, Tiberti C, Bonamico M, Taki I, Miao D, Murray JA, Rewers MJ, Hoffenberg EJ, Agardh D, Mueller P, Stern M, Bonifacio E, Liu E: A report on the International Transglutaminase Autoantibody Workshop for Celiac Disease. Am.J Gastroenterol 2009;104:154-163.

64. Liu E, Eisenbarth GS: Accepting clocks that tell time poorly: fluid-phase versus standard ELISA autoantibody assays. Clin Immunol 2007;125:120-126.

65. Liu E, Li M, Bao F, Miao D, Rewers MJ, Eisenbarth GS, Hoffenberg EJ: Need for quantitative assessment of trans- glutaminase autoantibodies for celiac disease in screeningidentified children. J Pediatr 2005;146:494-499.

66. Barker JM, Ide A, Hostetler C, Yu L, Miao D, Fain PR, Eisenbarth GS, Gottlieb PA: Endocrine and immunogenetic testing in individuals with type 1 diabetes and 21-hydroxylase autoantibodies: Addison's disease in a high-risk population. J Clin Endocrinol Metab 2005;90:128-134.

67. Zhang L, Barker JM, Babu S, Su M, Stenerson M, Cheng M, Shum A, Zamir E, Badolato R, Law A, Eisenbarth GS, Anderson MS: A robust immunoassay for anti-interferon autoantibodies that is highly specific for patients with autoimmune polyglandular syndrome type 1 . Clin Immunol 2007;125:131-137.

68. Deane KD, Norris JM, Holers VM: Preclinical rheumatoid arthritis: identification, evaluation, and future directions for investigation. Rheum Dis Clin North Am 2010;36:213-241.

69. Deane KD, O'Donnell CI, Hueber W, Majka DS, Lazar AA, Derber LA, Gilliland WR, Edison JD, Norris JM, Robinson WH, Holers VM: The number of elevated cytokines/chemokines in pre-clinical seropositive rheumatoid arthritis predicts time to diagnosis in an age-dependent manner. Arthritis Rheum 2010;62:3161-3172.

70. Ferucci ED, Majka DS, Parrish LA, Moroldo MB, Ryan M, Passo M, Thompson SD, Deane KD, Rewers M, Arend WP, Glass DN, Norris JM, Holers VM: Antibodies against cyclic citrullinated peptide are associated with HLA-DR4 in simplex and multiplex polyarticular-onset juvenile rheumatoid arthritis. Arthritis Rheum 2005;52:239-246.

71. Kolfenbach JR, Deane KD, Derber LA, O'Donnell CI, Gilliland WR, Edison JD, Rosen A, Darrah E, Norris JM, Holers VM: Autoimmunity to peptidyl arginine deiminase type 4 precedes clinical onset of rheumatoid arthritis. Arthritis Rheum 2010;62:2633-2639.

72. Yu L, Wang J, O'Dell JR, Oates J, Arend WP, Eisenbarth GS: Anti-dsDNA antibody assay: high specificity and sensitivity with a filtration radioassay in comparison to low specificity with the standard ELISA. J Rheumatol 2007; 34:734-739.

73. American Diabetes Association: Standards of medical care in diabetes-2007. Diabetes Care 2007;30(Suppl 1):S4-S41.

74. Hoffenberg EJ, MacKenzie T, Barriga KJ, Eisenbarth GS, Bao F, Haas JE, Erlich H, Bugawan TT, Sokol RJ, Taki I, Norris JM, Rewers M: A prospective study of the incidence of childhood celiac disease. J Pediatr 2003;143:308-314.

75. Hoffenberg EJ, Emery LM, Barriga KJ, Bao F, Taylor J, Eisenbarth GS, Haas JE, Sokol RJ, Taki I, Norris JM, Rewers M: Clinical features of children with screening-identified evidence of celiac disease. Pediatrics 2004;113:1254-1259.

76. Rewers M: Epidemiology of celiac disease: what are the prevalence, incidence, and progression of celiac disease? Gastroenterology 2005;128(4 Suppl 1):S47-S51.

77. Rewers M, Liu E, Simmons J, Redondo MJ, Hoffenberg EJ: Celiac disease associated with type 1 diabetes mellitus. Endocrinol Metab Clin North Am 2004;33:197-214, xi.

78. Simmons JH, Klingensmith GJ, McFann K, Rewers M, Taylor J, Emery LM, Taki I, Vanyi S, Liu E, Hoffenberg EJ: Impact of celiac autoimmunity on children with type 1 diabetes. J Pediatr 2007;150:461-466.

79. Simmons JH, Klingensmith GJ, McFann K, Rewers M, Ide LM, Taki I, Liu E, Hoffenberg EJ: Celiac autoimmunity in children with type 1 diabetes: a two-year follow-up. J Pediatr 2011;158:276-281.e1.

80. Simpson M, Mojibian M, Barriga K, Scott FW, Fasano A, Rewers M, Norris JM: An exploration of Glo-3A antibody 
levels in children at increased risk for type 1 diabetes mellitus. Pediatr Diabetes 2009;10:563-572.

81. Taplin CE, Mojibian M, Simpson M, Taki I, Liu E, Hoffenberg EJ, Norris JM, Scott FW, Rewers M: Antibodies to the wheat storage globulin Glo-3A in children before and at diagnosis of celiac disease. J Pediatr Gastroenterol Nutr 2011;52:21-25.

82. Baker PR, Baschal EE, Fain PR, Triolo TM, Nanduri P, Siebert JC, Armstrong TK, Babu SR, Rewers MJ, Gottlieb PA, Barker JM, Eisenbarth GS: Haplotype analysis discriminates genetic risk for DR3-associated endocrine autoimmunity and helps define extreme risk for Addison's disease. J Clin Endocrinol Metab 2010;95:E263-E270.

83. Barker JM, Yu J, Yu L, Wang J, Miao D, Bao F, Hoffenberg E, Nelson JC, Gottlieb PA, Rewers M, Eisenbarth GS: Autoantibody "subspecificity" in type 1 diabetes: risk for organspecific autoimmunity clusters in distinct groups. Diabetes Care 2005;28:850-855.

84. Chase HP, Palandri S: Diabetes: A History of a Center and a Patient. Denver, CO: The Children's Diabetes Foundation at Denver, 2011.

85. The Environmental Determinants of Diabetes in the Young (TEDDY) Study. Ann N Y Acad Sci 2008;1150:1-13.

86. Hagopian WA, Erlich H, Lernmark A, Rewers M, Ziegler AG, Simell O, Akolkar B, Vogt R, Jr., Blair A, Ilonen J, Krischer J, She J: The Environmental Determinants of Diabetes in the Young (TEDDY): genetic criteria and international diabetes risk screening of 421000 infants. Pediatr Diabetes 2011;12:733-743.

87. Bonifacio E, Yu L, Williams AK, Eisenbarth GS, Bingley PJ, Marcovina SM, Adler K, Ziegler AG, Mueller PW, Schatz DA, Krischer JP, Steffes MW, Akolkar B: Harmonization of glutamic acid decarboxylase and islet antigen-2 autoantibody assays for National Institute of Diabetes and Digestive and Kidney Diseases Consortia. J Clin Endocrinol Metab 2010;95:3360-3367.

88. Michels AW, Ostrov DA, Zhang L, Nakayama M, Fuse M, McDaniel K, Roep BO, Gottlieb PA, Atkinson MA, Eisenbarth GS: Structure-based selection of small molecules to alter allele-specific MHC class II antigen presentation. J Immunol 2011;187:5921-5930.

89. Eisenbarth GS: Banting Lecture 2009: an unfinished journey: molecular pathogenesis to prevention of type $1 \mathrm{~A}$ diabetes. Diabetes 2010;59:759-774.

Address correspondence to: Marian Rewers, MD, PhD Barbara Davis Center for Diabetes University of Colorado School of Medicine 1775 Aurora Court, A-140 Aurora, CO 80045

E-mail: marian.rewers@ucdenver.edu 


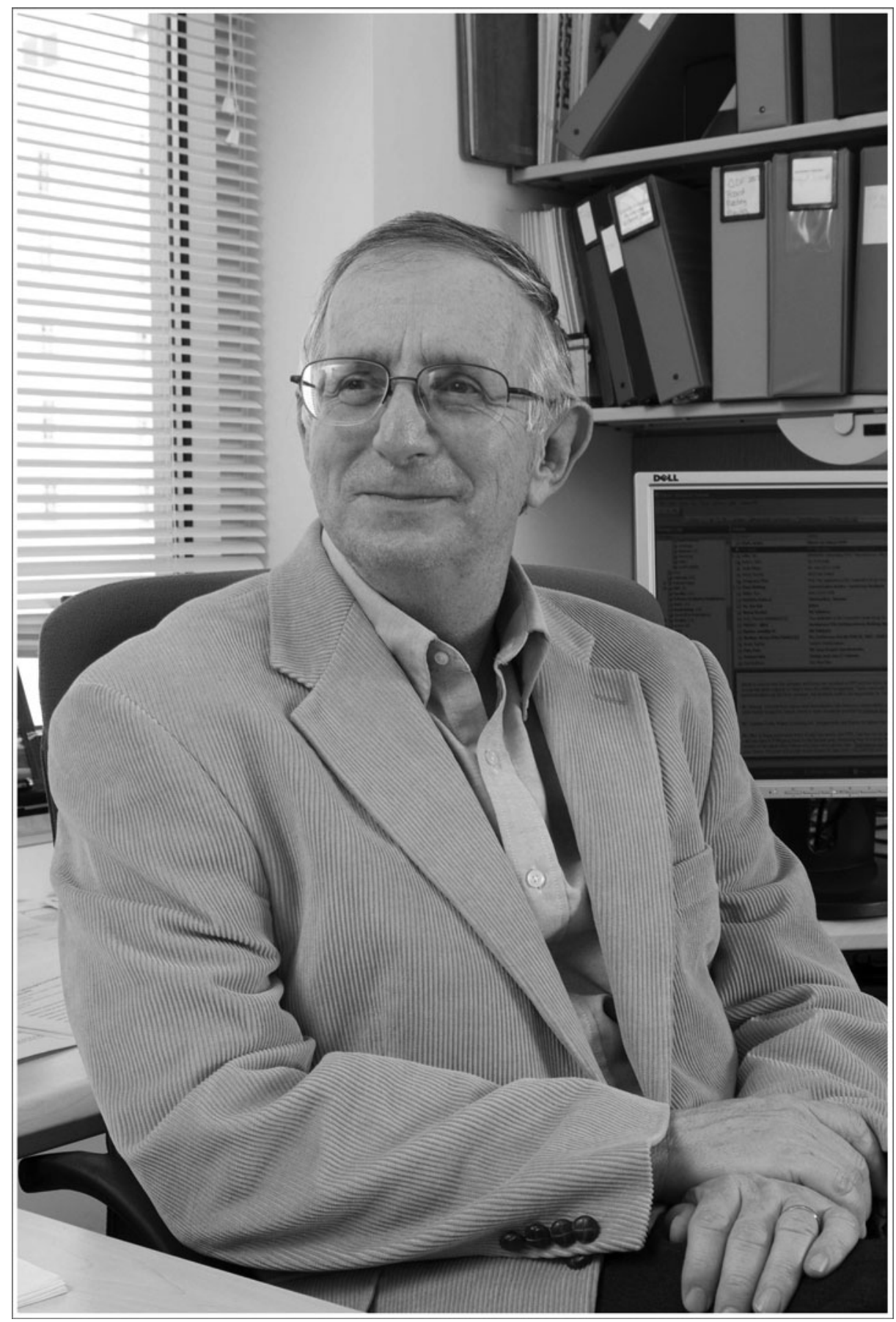

George Eisenbarth 